\title{
Aloe Vera Gel Effect on Skin and Pharmacological Properties
}

\author{
Aisha Saleem ${ }^{1 *}$, Irum Naureen ${ }^{2}$, Muhammad Naeem ${ }^{3}$, Hafiza Safoora Murad ${ }^{1}$, Samra Maqsood ${ }^{1}$, Gulnaz Tasleem ${ }^{1}$ \\ ${ }^{1}$ M. Phil Researcher, School of Zoology, Minhaj University Lahore, Pakistan \\ ${ }^{2}$ Assistant Professor, School of Zoology, Minhaj University Lahore, Pakistan \\ ${ }^{3}$ Institute of Research and Information Mirpur AJK, Pakistan
}

DOI: $10.36348 /$ sijap.2022.v05i01.001 | Received: 02.12.2021 | Accepted: 04.01.2022 | Published: 07.01 .2022

*Corresponding author: Aisha Saleem

M. Phil Researcher, School of Zoology, Minhaj University Lahore, Pakistan

\section{Abstract}

Aloe Vera, a cactus-like plant belongs to Asphodelaceae (Liliaceae) family has been used for traditional medical purposes for thousands of years. Aloe Vera derives its name from the Arabic word "Alloeh" which means "shining bitter substance" because of the bitter liquid found in the leaves and Vera which means "true" in Latin. There are over 300 species of aloe, most of which are native to South Africa, Madagascar and Arabia. Aloe leaves can be separated into two basic products: the latex, a bitter yellow liquid beneath the epidermis of the leaf and the gel, a colorless and tasteless substance in the inner part of the leaf. Both of them have many biologically active components, mainly anthraquinones and polysaccharides (the most active is acemannan), which may act alone or in synergy. Application of Aloe vera gel is cosmetic-moisturizers, toothpastes and flavoring compounds or preservative of fresh products and in medicine of humans or animals. Aloe vera gel is an active ingredient in hundreds of skin lotions, sun blocks and cosmetics. Aloe vera seems to treat of wounds, burns, insect stings, and skin inflammation, anti-inflammatory, antiseptic and antimicrobial, antitumor, anti- skin protection, anti-diabetic, anti-bacterial, anti-viral, and which are very important for wound healing. Aloe Vera gel helps in activating new hair growth as it increases blood circulation to the scalp. It also provides essential minerals and vitamins.

Keywords: Aloe vera gel, Skin diseases, Medicinal Plant, Wound healing, Anti-inflammatory, pharmacological properties.

Copyright (C) 2022 The Author(s): This is an open-access article distributed under the terms of the Creative Commons Attribution 4.0 International License (CC BY-NC 4.0) which permits unrestricted use, distribution, and reproduction in any medium for non-commercial use provided the original author and source are credited.

\section{INTRODUCTION}

Aloe Vera is derived from the tropical cactus of the genus aloe. Aloe Vera derives its name from the Arabic word "Alloeh" which means "shining bitter substance" because of the bitter liquid found in the leaves and Vera which means "true" in Latin [1, 2]. Aloe Vera is Aloe barbadensis miller. It belongs to Asphodelaceae (Liliaceae) family, and is a shrubby or arborescent, perennial, xerophytic, succulent, pea-green color plant. The aloe plant has long (up to 20 inches long and 5 inches wide), triangular, fleshy leaves that have spikes along the edges. The fresh parenchymal gel from the center of the leaf is clear; this part is sometimes dried to form aloe Vera concentrate or diluted with water to create aloe juice products [3].

The sticky latex liquid is derived from the yellowish green pericyclic tubules that line the leaf (rind); this is the part that yields laxative anthraquinones [4]. There are over 300 species of aloe, most of which are native to South Africa, Madagascar and Arabia [5]. The different species have somewhat different concentrations of active ingredients [6]. Aloe Vera is one of the oldest medicinal plants for healthy skin ever known. This plant is often mentioned used in herbal medicines since the beginning of the first century AD [7].

Aloe Vera (AV) gel has been used in the treatment of wounds, burns, insect stings, and skin inflammation, anti-inflammatory, antiseptic and antimicrobial, anti-tumor, anti- skin protection, antidiabetic, anti-bacterial, anti-viral, and whic 11 are very important for wound healing [8,9]. AV is effective for wound healing through various mechanisms such as maintaining moist wounds, increasing cell migration, increasing collagen production, and reducing inflammation [10]. 


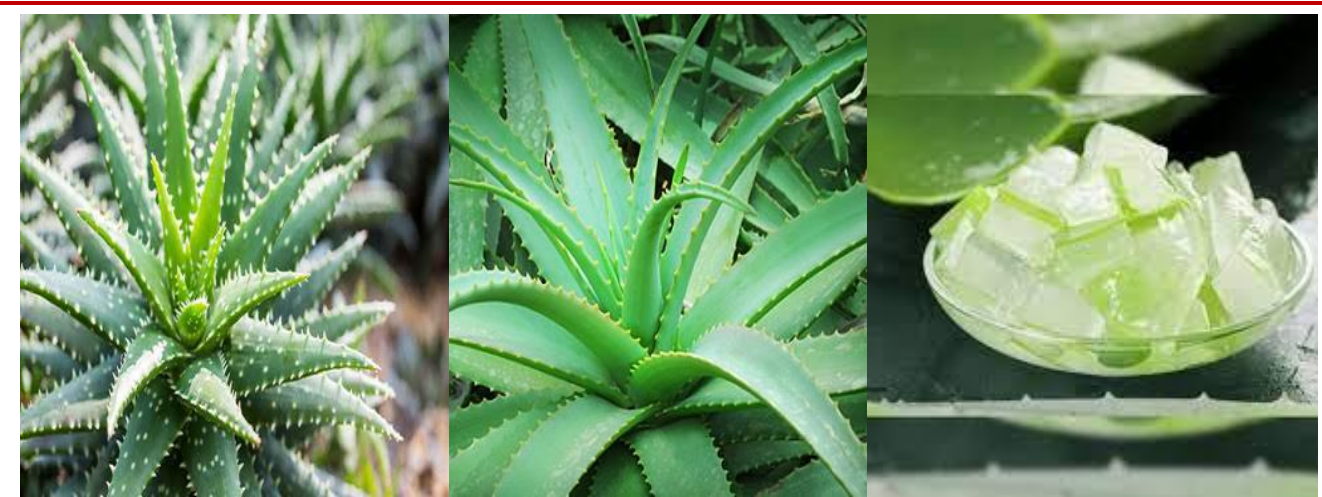

Figure 1: Aloe vera plant and Aloe vera gel [11]

Aloe vera is a stemless or very short-stemmed plant growing to 60-100 centimetres (24-39 inches) tall, spreading by offsets [12]. The leaves are thick and fleshy, green to grey-green, with some varieties showing white flecks on their upper and lower stem surfaces [13]. Aloe vera leaves contain phytochemicals under study for possible bioactivity, such as acetylated mannans, polymannans, anthraquinone Cglycosides, anthrones, and other anthraquinones, such as emodin and various lectins [14]. Aloe vera can lead to skin integrity, moisture retention, erythema reduction, and helps to prevent skin ulcers [15].

Aloe vera to treat wounds such as psoriasis, mouth sores, ulcers, diabetes, herpes, bedsores, and burn wounds $[16,17]$. AV is very good at maintaining moisture, tightening, and smoothing the skin [18]. Aloe vera gel is an active ingredient in hundreds of skin lotions, sun blocks and cosmetics [19]. AV gel contains various vitamins such as vitamin $\mathrm{B} 12$, vitamin $\mathrm{A}$, other B-group vitamins, vitamin $\mathrm{C}$, vitamin $\mathrm{E}$, folic acid, and 19 of the 20 amino acids needed by the human body [22]. The gel's use in cosmetics has been boosted by claims that it has similar anti-aging effects to vitamin A derivatives [20]. When faced with a minor burn, a fresh leaf can be cut and the gel of the inner leaf applied directly to the burn immediately after the injury [21].

\section{Chemical composition of Aloe vera gel}

The leaf of A. Vera composed of mainly three layers. Rind is the outer thick layer containing of 15-20 cells which synthesizes carbohydrates and proteins. Inside the rind, vascular bundles are present such as xylem and phloem [23].

\begin{tabular}{|c|c|c|c|}
\hline Class & Compounds & Properties & References \\
\hline $\begin{array}{l}\text { Anthraquinones/ } \\
\text { anthrones }\end{array}$ & $\begin{array}{l}\text { Aloe-emodin, aloetic-acid, anthranol, } \\
\text { barbaloin, isobarbaloin, emodin, ester of } \\
\text { cinnamic acid. }\end{array}$ & $\begin{array}{l}\text { Aloin and emodin acts as analgesics, anti- } \\
\text { bacterials and antivirals. }\end{array}$ & [23] \\
\hline Carbohydrates & $\begin{array}{l}\text { Pure mannan, acetylated mannan, } \\
\text { acetylated galactan, xylan, cellulose, } \\
\text { glucomannan, glucogalactomannan, } \\
\text { galactogalacturan, arabinogalactan,, } \\
\text { galactoglucoarabino mannan, pectic } \\
\text { substance }\end{array}$ & $\begin{array}{l}\text { A glycoprotein with anti allergic } \\
\text { properties, called alprogen and novel anti- } \\
\text { inflammatory compound. }\end{array}$ & [24] \\
\hline Chromones & $\begin{array}{l}\text { 8-C-glusoly-(2'-O-cinnamoly) -7-O- } \\
\text { Methylaloediol A,8-C-glucosyl-(S)- } \\
\text { aloesol,8-C-glucosyl-7-O methylaloediol } \\
\text { A, 8-C-glucosyl-7-0-methylaloediol, 8-C- } \\
\text { glucosyl-noreugenin, isoaloeresin D, iso } \\
\text { rabai chromone, neoalosin A }\end{array}$ & The novel anti-inflammatory commands. & [25] \\
\hline Enzymes & $\begin{array}{l}\text { Alkaline phosphatese, amylase, brady } \\
\text { kinase, carboxy-peptidase, catalase, } \\
\text { cyclo-oxidase, lipase, oxidase, cyclo- } \\
\text { oxygenase, phosphoenol pyruvate, } \\
\text { carboxylase, superoxide dismutase. }\end{array}$ & $\begin{array}{l}\text { Brady kinase helps to reduce excessive } \\
\text { inflammation when applied to the skin } \\
\text { topically, while others help in the } \\
\text { breakdown of sugars and fats }\end{array}$ & [26] \\
\hline $\begin{array}{l}\text { In-organic } \\
\text { compounds }\end{array}$ & $\begin{array}{l}\text { Calcium, chlorine, chromium, copper, } \\
\text { iron, magnesium, manganese, potassium, } \\
\text { phosphorous, sodium, Zinc. }\end{array}$ & $\begin{array}{l}\text { They are essential for the proper } \\
\text { functioning of various enzymes systems in } \\
\text { different metabolic pathways and few are } \\
\text { antioxidants. }\end{array}$ & [27] \\
\hline $\begin{array}{l}\text { Miscellaneous } \\
\text { including organic } \\
\text { compounds and }\end{array}$ & $\begin{array}{l}\text { Arachidonic acid, Y-linolenic acid, } \\
\text { steroids (campestrol-cholesterol, } \\
\text { Bsitosterol), triglycerides, salicylic acid }\end{array}$ & Essential for the proper functioning & {$[22,24]$} \\
\hline
\end{tabular}


Aisha Saleem et al; Sch Int J Anat Physiol, Jan., 2022; 5(1): 1-8

\begin{tabular}{|l|l|l|l|}
\hline Class & Compounds & Properties & References \\
\hline lipids & $\begin{array}{l}\text { triterpenoid, gibberillin, lignins, } \\
\text { potassium, sorbate, uric acid }\end{array}$ & $\begin{array}{l}\text { It also contains salicylic acid that } \\
\text { possesses anti-inflammatory and } \\
\text { antibacterial properties. Lignin, an inert } \\
\text { substance, when included in topical } \\
\text { preparations, enhances penetrative effect } \\
\text { of the other ingredients into skin. } \\
\text { Siphoning that is the soapy substances } \\
\text { from about 3\% of the gel and has } \\
\text { cleansing and antiseptic properties. }\end{array}$ & [28] \\
\hline Saccharides & $\begin{array}{l}\text { Lectins, lectin-like substance } \\
\text { aldopentose }\end{array}$ & $\begin{array}{l}\text { Show antiseptic properties } \\
\text { Vannose, glucose, L-rhamnose, }\end{array}$ & [25] \\
\hline Vitamins & $\begin{array}{l}\text { Vitamin A, B12,C, E, choline and folic } \\
\text { acid }\end{array}$ & $\begin{array}{l}\text { Vitamin A, C and E are antioxidants and } \\
\text { antioxidant neutralizes free radicals }\end{array}$ & [29] \\
\hline Hormones & Auxins and gibberellins & $\begin{array}{l}\text { That helps in wound healing and have anti } \\
\text { inflammatory action }\end{array}$ & [26] \\
\hline
\end{tabular}

Aloe gel is $99 \%$ water with a $\mathrm{pH}$ of 4.5 and is a common ingredient in many non-prescription skin salves. The gel contains an emollient polysaccharide, glucomannan. It is a good moisturizer [30].

\section{Moisturization Protection from radiation}

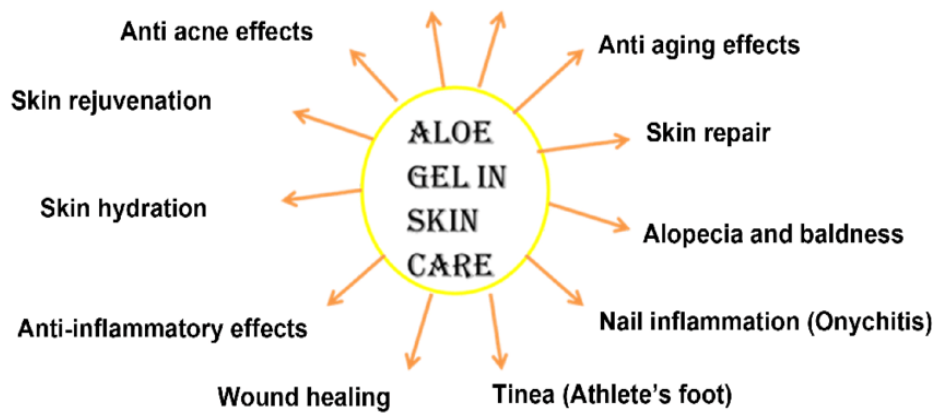

Fig 2: Use of aloe gel in skin care. [61, 62]

\section{Mechanism action of Aloe vera gel [31]}

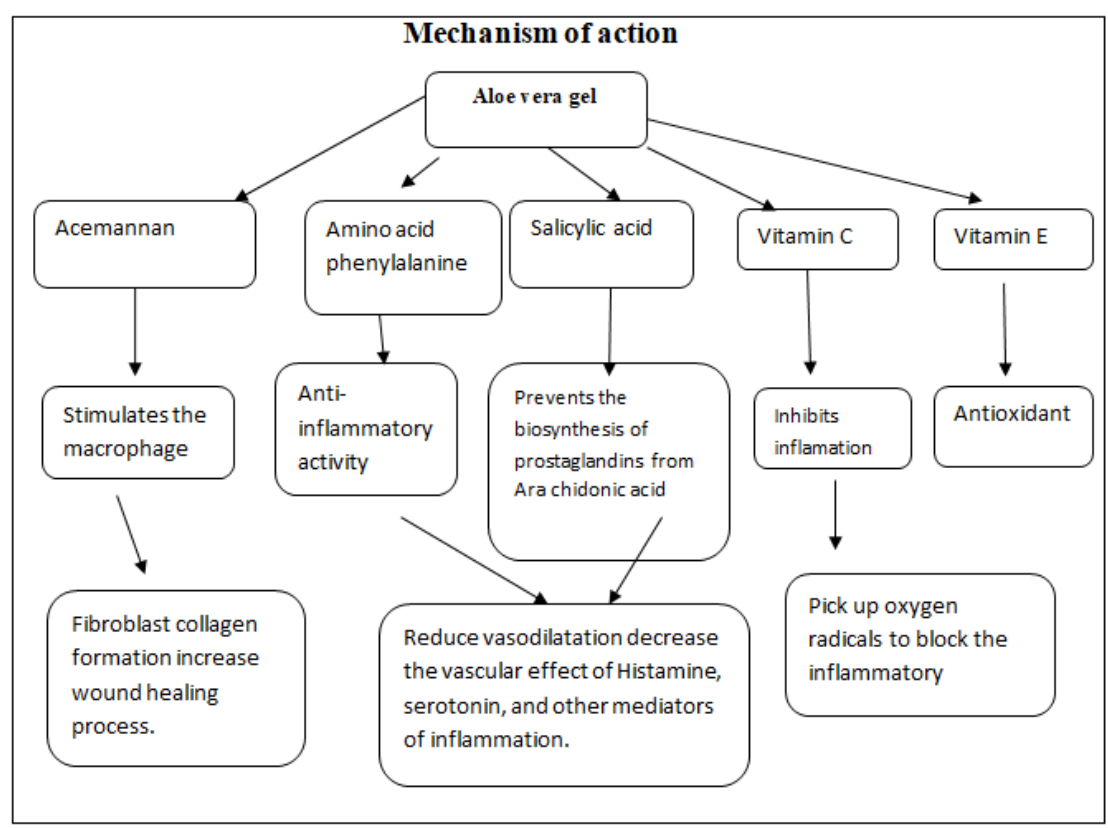


Aisha Saleem et al; Sch Int J Anat Physiol, Jan., 2022; 5(1): 1-8

\section{Pharmacological Properties of Aloe vera gel Wound Healing properties}

The effective components for wound healing may be tannic acid, and a type of polysaccharide. Wound healing is a mechanism of repairing damaged tissues in human body [32]. Mannose-6-phosphate found in the mucilaginous gel of $A$. Vera is considered to be the active ingredient for wound healing. Aloe vera on wound healing was assessed by collagen thickness and the number of fibroblasts [33]. The number of fibroblasts in the full-thickness defect treated with ozonated Aloe vera oil was higher than that treated with Aloe vera oil only and gentamicin ointment [34]. Ozonated ointment increases reactive oxygen species (ROS) at the wound site acting as a secondary messenger for various immunocytes and nonlymphoid cells involved in the wound repair process and plays a pivotal role in coordinating the recruitment of lymphoid cells to the wound site and effective tissue repair.

Wound healing and preventive effects of Aloe vera to prevent ulcers and enhance the healing process of dermal injuries (e.g., burns, frostbite, skin infections, surgical wounds, inflammation, herpes ulcers, diabetic foot ulcers, pressure sores, and chronic wounds) has been reported [35]. Aloe vera was more effective than petroleum jelly gauze dressing, silver sulfadiazine $1 \%$ ointment, and framycetin cream. It reduced the recovery time, prevented infection in the wound area, and prevented redness and itching [36].

\section{Effects on skin exposure to UV and gamma radiation}

Aloe Veras support the healing of first to second degree burns and have a protective effect against damage to skin [37, 53]. Aloe vera gel, an antioxidant protein, metallothionein, is generated in the skin which scavenges hydroxyl radicals and prevents suppression of superoxide dismutase and glutathione peroxidase in the skin. It reduces the production and release of skin keratinocyte-derived immunosuppresive cytokines such as interlukin -10 and hence prevents UV-induced suppression of delayed type hypersensitivity $[38,54]$.

\section{Antibacterial properties}

Aloe vera inhibits the growth of some microorganisms like Str. pyogenes, Shigella flexneri, Klebsiella sp., especially against Gram-positive bacteria causing food poisoning or diseases in humans and animals [53].

\section{Anti-oxidant / Antiseptic effect}

Aloe vera possesses enormous antioxidant effect. Glutathione peroxidise activity, superoxide dismutase enzymes and a phenolic anti-oxidant were found to be present in Aloe Vera gel, which may be responsible for these anti-oxidant effects [39]. Aloe vera enhances the blood quality, probably by allowing the blood to more effectively transport oxygen and nutrients to the cells of body [40].

Aloe vera contains 6 antiseptic agents: Lupeol, salicylic acid, urea nitrogen, cinnamonic acid, phenols and sulfur. They all have inhibitory action on fungi, bacteria and viruses [41].

\section{Anti - inflammatory action}

Inflammation is an innate response of the body against an injury, characterized by swelling, pain, redness and heat, resulting in delay in the healing process [42]. The anti-inflammatory action of Aloe vera gel not only relieves from pain and discomfort, but also accelerates the healing process. The effects observed for acetylated mannan in Aloe gel resembles the antiinflammatory action of mannose-6-phosphate [40, 43]. Aloe vera also inhibits the cyclooxygenase pathway, reducing the production of prostaglandins, thereby reducing the inflammation. The aqueous and chloroform extracts of Aloe vera were found to have anti oedema effects. Further, they were found to decrease the neutrophil count progressing towards the peritoneal cavity. Aloe vera also showed a great antiinflammatory potential for the treatment of $\mathrm{H}$. Pylori infection [44].

\section{Anti-acne effect}

Acne is the most common disease of skin which causes trouble in adolescent and adult life. [45] Aloe vera are very effective against acne and inflammation on any area of skin e.g. it consists of vitamins, minerals and hormones. It is hydrophilic in nature so very effective to use for oily skin [46]. Aloe vera emulgel helped to reduce the flare of acne, contains the olive oil, rose oil and lemon oil also that deeply penetrates into skin and provides cleansing and smoothing effect over the skin [47]. It has also moisturizing property that protects the skin from over dry which is not good for acne prone skin [48]. Olive oil has antioxidant and anti-bacterial property that helpful in fighting against inflammatory cells to reduce inflammation [50]. Rose oil and lemon oil has cleansing action and clears the pores from inflammatory bacteria Propylene glycol, another ingredient in Aloe vera emulgel, used as humectant solvent. It is non-irritant to skin and aids deeply penetration of drug into skin [51, 52].

\section{Moisturizing and anti-aging effect}

Aloe vera is currently utilized in manufacturing more than $95 \%$ of the dermatologically valuable products. This is because it possesses implausible moisturizing properties [19]. It improves the ability of skin to hydrate itself and help in removal of dead skin cells that producing collagen and elastin fibers, making the skin more elastic, and less wrinkled, thereby, reversing the degenerative skin changes. It softens the skin, by its cohesive action on superficial 
Aisha Saleem et al; Sch Int J Anat Physiol, Jan., 2022; 5(1): 1-8

flaking epidermal cells and also by the action of amino acids [41].

\section{Anti-diabetic effects}

Aloe vera gel is well known for reducing the blood sugar level. Aloe vera gel (alcohol insoluble residue extract) significantly reduced the fasting blood glucose, herpatic transminases, plasma and tissue cholestrol, triglicerides [57], free fatty acids and phospholipids and in addition also significantly increased plasma insulin levels. Aloe vera extarcts to reduced blood glucose levels is by enchancing glucose metabolism [58].

\section{Uses / benefits of Aloe vera gel}

It is used as base material for the production of creams, lotions, soaps, shampoos, facial cleansers and other products. In the pharmaceutical industry, it is used for the manufacturing of topical products such as ointments and gel preparations, as well as in the production of tablets and capsules dried aloe gel has been successfully used to manufacture directly compressible matrix type tablets.

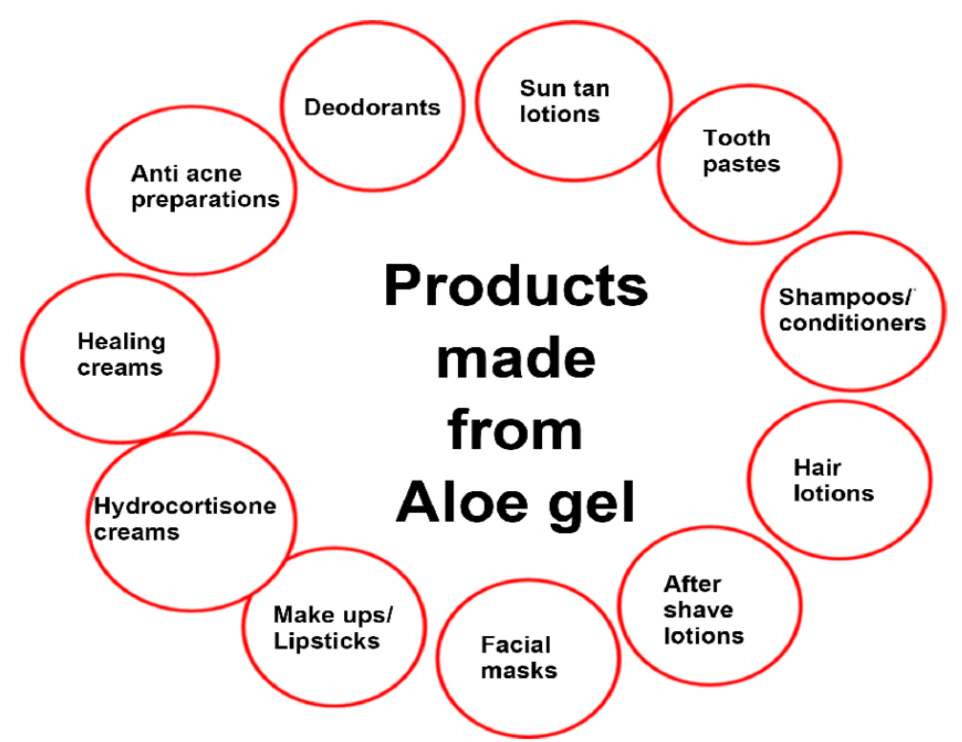

Fig 3: Aloe gel made different cosmetic products [58]

\begin{tabular}{|l|l|}
\hline Benefits & References \\
\hline Aloe vera is considered a natural laxative. & {$[\mathbf{3 8}]$} \\
\hline Aloe vera to keep skin clear and hydrated & {$[\mathbf{3 0}]$} \\
\hline Aloe vera Potential to fight breast cancer & {$[\mathbf{5 3}]$} \\
\hline Aloe vera juice use can cause blood sugar levels is low in diabetic patients. & {$[\mathbf{5 7 , 5 8}]$} \\
\hline $\begin{array}{l}\text { Aloe Vera gel helps in activating new hair growth as it increases blood circulation to the scalp. It also } \\
\text { provides essential minerals and vitamins. }\end{array}$ & {$[\mathbf{6 2}]$} \\
\hline $\begin{array}{l}\text { Aloe Vera helps in healing dry skin, fungal infections and excessively oily skin. The natural ways to } \\
\text { get rid of dandruff. }\end{array}$ & {$[\mathbf{6 3}]$} \\
\hline $\begin{array}{l}\text { The nourishing and healing properties of aloe vera work to restore skin to its former suppleness. } \\
\text { Beneficial for face and foot skin. }\end{array}$ & {$[\mathbf{3 3 , 3 6}$} \\
\hline It may improve skin and prevent wrinkles & {$[\mathbf{6 1}]$} \\
\hline It reduces dental plaque & $\mathbf{4 3 3}$ \\
\hline
\end{tabular}

\section{CONCLUSION}

Aloe vera is a medicinal plant and curing agent for various diseases such as wounds healing, inflammation, cancer, liver diseases, microbial diseases, skin problems cardio vascular disorders, ulcer, free radical related diseases, diabetes, and others. The cultivation of Aloe vera has acquired great commercial importance for medicinal products and cosmetics. Aloe vera is widely used in food, healthcare, skincare and medical industry as active ingredients for extra therapeutic, health enhance effectives. Aloe Vera improves skin moisture from the texture of roughness, shines, cracks, and scrapes. Aloe vera emulgel formulation due to its anti-inflammatory, anti-acne, anti-oxidant, anti-diabetic non- irritant and deeply penetrating properties helps the skin nourishment to turn into normal position with soothing and emollient effects.

\section{REFERENCES}

1. Gage, D. (1996). Aloe vera: Natures Soothing Healer. Healing Acts Press, Rochester, Vermont, USA, 120 p. 3. 
Aisha Saleem et al; Sch Int J Anat Physiol, Jan., 2022; 5(1): 1-8

2. Surjushe, A., Vasani, R., \& Saple, D. G. (2008). Aloe vera: a short review. Indian journal of dermatology, 53(4), 163-166.

3. Schulz, V., Hansel, R., \& Tyler, V. E. (1997). Rational Phyto therapy: A Physicians' Guide to Herbal Medicine. Berlin: Springer, 306.

4. Christaki, E. V., \& Florou-Paneri, P. C. (2010). Aloe vera: a plant for many uses. J Food Agric Environ, 8(2), 245-249.

5. Yagi, A., Tsunoda, M., Egusa, T., Akasaki, K., \& Tsuji, H. (1998). Immunochemical distinction of Aloe vera, A. arborescens, and A. chinensis gels. Planta medica, 64(03), 277-278.

6. Van Wyk, B. E., Van Oudtshoorn, M. V. R., \& Smith, G. F. (1995). Geographical variation in the major compounds of Aloe ferox leaf exudate. Planta Medica, 61(03), 250-253.

7. Saito, M., Tanaka, M., Misawa, E., Yao, R., Nabeshima, K., Yamauchi, K., ... \& Furukawa, F. (2016). Oral administration of Aloe vera gel powder prevents UVB-induced decrease in skin elasticity via suppression of overexpression of MMPs in hairless mice. Bioscience, biotechnology, and biochemistry, 80(7), 1416-1424.

8. García, M. H., Juárez, J. A. T., \& Jiménez, A. D. (2019). Importance and Properties of Aloe vera in the Production of Hair Shampoo. The Journal of Middle East and North Africa Sciences, 5(7), 1823.

9. Guenther, L., Lynde, C. W., Andriessen, A., Barankin, B., Goldstein, E., Skotnicki, S. P., ... \& Sloan, K. (2012). Pathway to dry skin prevention and treatment. Journal of cutaneous medicine and surgery, 16(1), 23-31.

10. Komatsu, D., Mistura, D. V., Motta, A., Domingues, J. A., Hausen, M. A., \& Duek, E. (2017). Development of a membrane of poly (L-co$\mathrm{D}$, L lactic acid-co-trimethylene carbonate) with aloe vera: An alternative biomaterial designed to improve skin healing. Journal of biomaterials applications, 32(3), 311-320.

11. Sharrif Moghaddasi, M., \& Res, M. (2011). Aloe vera their chemicals composition and applications: A review. Int J Biol Med Res, 2(1), 466-471.

12. King, G. K., Yates, K. M., Greenlee, P. G., Pierce, K. R., Ford, C. R., McAnalley, B. H., \& Tizard, I. R. (1995). The effect of Acemannan Immunostimulant in combination with surgery and radiation therapy on spontaneous canine and feline fibrosarcomas. Journal of the American Animal Hospital Association, 31(5), 439-447.

13. Eshun, K., \& He, Q. (2004). Aloe vera: a valuable ingredient for the food, pharmaceutical and cosmetic industries - a review. Critical reviews in food science and nutrition, 44(2), 91-96.

14. Dat, A. D., Poon, F., Pham, K. B., \& Doust, J. (2012). Aloe vera for treating acute and chronic wounds. Cochrane Database of Systematic Reviews, (2).
15. Ghaffarzadegan, R., Alizadeh, S. A., Ghaffarzadegan, R., Haji Agaei, R., \& Ahmadlou, M. (2013). Effect of aloe vera gel, compared to $1 \%$ silver sulfadiazine cream on second-degree burn wound healing. Complementary Medicine Journal, 3(1), 418-428.

16. Sahu, P. K., Giri, D. D., Singh, R., Pandey, P., Gupta, S., Shrivastava, A. K., ... \& Pandey, K. D. (2013). Therapeutic and medicinal uses of Aloe vera: a review. Pharmacology \& Pharmacy, 4(08), 599-610.

17. Maenthaisong, R., Chaiyakunapruk, N., Niruntraporn, S., \& Kongkaew, C. (2007). The efficacy of aloe vera used for burn wound healing: a systematic review. burns, 33(6), 713-718.

18. Grindlay, D., \& Reynolds, T. (1986). The Aloe vera phenomenon: a review of the properties and modern uses of the leaf parenchyma gel. Journal of ethnopharmacology, 16(2-3), 117-151.

19. West, D. P., \& Zhu, Y. F. (2003). Evaluation of aloe vera gel gloves in the treatment of dry skin associated with occupational exposure. American Journal of Infection Control, 31(1), 40-42.

20. Danhof, I. E. (1993). Potential reversal of chronological and photo-aging of the skin by topical application of natural substances. Phytotherapy Research, 7(7), S53-S56.

21. Ship, A. G. (1977). Is Topical Aloe Vera Plant Mucus Helpful In Burn-Treatment. Jama-Journal of the American Medical Association, 238(16), 1770-1770.

22. Khadar, A., Behara, D. K., \& Kumar, M. K. (2016). Synthesis and characterization of controlled size $\mathrm{TiO} 2$ nanoparticles via green route using Aloe vera extract. International Journal of Science and Research (IJSR), 5(1), 1913-1916.

23. Ni, Y., \& Tizard, I. R. (2004). Analytical methodology: the gel-analysis of aloe pulp and its derivatives. In Aloes the Genus Aloe; Reynolds, T., Ed.; CRC Press: Boca Raton. pp. 111-126.

24. Dagne, E., Bisrat, D., Viljoen, A., \& Van Wyk, B. E. (2000). Chemistry of Aloe species. Current Organic Chemistry, 4(10), 1055-1078.

25. Femenia, A., Sánchez, E. S., Simal, S., \& Rosselló, C. (1999). Compositional features of polysaccharides from Aloe vera (Aloe barbadensis Miller) plant tissues. Carbohydrate polymers, 39(2), 109-117.

26. Choi, S., \& Chung, M. H. (2003, March). A review on the relationship between Aloe vera components and their biologic effects. In Seminars in integrative medicine, 1(1), pp. 53-62.

27. Surjushe, A., Vasani, R., \& Saple, D. G. (2008). Aloe vera: a short review. Indian journal of dermatology, 53(4), 163-166.

28. Hamman, J. H. (2008). Composition and applications of Aloe vera leaf gel. Molecules, 13(8), 1599-1616. 
Aisha Saleem et al; Sch Int J Anat Physiol, Jan., 2022; 5(1): 1-8

29. Klein, A. D., \& Penneys, N. S. (1988). Aloe vera. Journal of the American Academy of Dermatology, 18(4), 714-720.

30. Henry, R. (1979). An updated review of Aloe vera. Cosmetics and toiletries, 94, 42-50.

31. Jawaid, M., Panat, S. R., Aggarwal, A., Upadhayay, N., Aggarwal, N., \& Durgvanshi, A. (2016). Aloe vera in oral diseases: Move toward the Nature. J Dent Sci Oral Rehab, 7(2), 67-73.

32. Phillips, T., Ongenae, K., Kanj, L., \& Slaterfreedberg, J. (1995). A randomized study of an aloe vera derivative gel dressing versus conventional treatment after shave biopsy excisions. Wounds-A Compendium of Clinical Research and Practice, 7(5), 200-202.

33. Maenthaisong, R., Chaiyakunapruk, N., Niruntraporn, S., \& Kongkaew, C. (2007). The efficacy of aloe vera used for burn wound healing: a systematic review. burns, 33(6), 713-718.

34. Travagli, V., Zanardi, I., Valacchi, G., \& Bocci, V. (2010). Ozone and ozonated oils in skin diseases: a review. Mediators of inflammation, 2010.

35. Moghbel, A., Ghalambor, A., \& Allipanah, S. (2007). Wound healing and toxicity evaluation of Aloe vera cream on outpatients with second degree burns. Iranian Journal of Pharmaceutical Sciences, 3(3), 157-160.

36. Sabzaligol, M., Safari, N., Baghcjeghi, N., Latifi, M., Bekhradi, R., Taghizadeh, M., \& Zareie, F. (2014). The effect of Aloevera gel on prineal pain \& wound healing after episiotomy. Complementary Medicine Journal, 4(2), 766-775.

37. Reynolds, T., \& Dweck, A. C. (1999). Aloe vera leaf gel: a review update. Journal of ethnopharmacology, 68(1-3), 3-37.

38. Roberts, D. B., \& Travis, E. L. (1995). Acemannan-containing wound dressing gel reduces radiation-induced skin reactions in $\mathrm{C} 3 \mathrm{H}$ mice. International Journal of Radiation Oncology* Biology* Physics, 32(4), 1047-1052.

39. Hamman, J. H. (2008). Composition and applications of Aloe vera leaf gel. Molecules, 13(8), 1599-1616.

40. Langmead, L., Makins, R. J., \& Rampton, D. S. (2004). Anti-inflammatory effects of aloe vera gel in human colorectal mucosa in vitro. Alimentary pharmacology \& therapeutics, 19(5), 521-527.

41. Surjushe, A., Vasani, R., \& Saple, D. G. (2008). Aloe vera: a short review. Indian journal of dermatology, 53(4), 163-166.

42. Vázquez, B., Avila, G., Segura, D., \& Escalante, B. (1996). Antiinflammatory activity of extracts from Aloe vera gel. Journal of ethnopharmacology, 55(1), 69-75.

43. Prabjone, R., Thong-Ngam, D., Wisedopas, N., Chatsuwan, T., \& Patumraj, S. (2006). Antiinflammatory effects of Aloe vera on leukocyteendothelium interaction in the gastric microcirculation of Helicobacter pylori-infected rats. Clinical hemorheology and

microcirculation, 35(3), 359-366.

44. Madan, J., Sharma, A. K., Inamdar, N., Rao, H. S., \& Singh, R. (2008). Immunomodulatory properties of Aloe vera gel in mice, International Journal of Green Pharmacy, 2(3), 152-154.

45. Surjushe, A., Vasani, R., \& Saple, D. (2008). Aloe Vera: a short review. Indian journal of dermatology, 53(4), 163.

46. Sánchez, M., González-Burgos, E., Iglesias, I., \& Gómez-Serranillos, M. P. (2020). Pharmacological update properties of Aloe vera and its major active constituents. Molecules, 25(6), 1324.

47. Al-Qudah, T. S., Zahra, U., Rehman, R., Majeed, M. I., Sadique, S., Nisar, S., ... \& Tahtamouni, R. W. (2018). Lemon as a source of functional and medicinal ingredient: A review. International Journal of Chemical and Biochemical Sciences, 14, 55-61.

48. Lozano-Sánchez, J., Giambanelli, E., QuirantesPiné, R., Cerretani, L., Bendini, A., SeguraCarretero, A., \& Fernández-Gutiérrez, A. (2011). Wastes generated during the storage of extra virgin olive oil as a natural source of phenolic compounds. Journal of Agricultural and Food Chemistry, 59(21), 11491-11500.

49. Bradley, J. C., Abraham, M. H., Acree, W. E., \& Lang, A. S. (2015). Predicting Abraham model solvent coefficients. Chemistry Central Journal, 9(1), 1-10.

50. Lin, T. K., Zhong, L., \& Santiago, J. L. (2018). Anti-inflammatory and skin barrier repair effects of topical application of some plant oils. International journal of molecular sciences, 19(1), 70.

51. Lucas, L., Russell, A., \& Keast, R. (2011). Molecular mechanisms of inflammation. Antiinflammatory benefits of virgin olive oil and the phenolic compound oleocanthal. Current pharmaceutical design, 17(8), 754-768.

52. Boukhatem, M. N., Ferhat, M. A., Kameli, A., Saidi, F., \& Kebir, H. T. (2014). Lemon grass (Cymbopogon citratus) essential oil as a potent anti-inflammatory and antifungal drugs. Libyan Journal of Medicine, 9(1).

53. Sato, Y., Ohta, S., \& Shinoda, M. (1990). Studies on chemical protectors against radiation. XXXI. Protection effects of Aloe arborescens on skin injury induced by X-irradiation. Yakugaku zasshi: Journal of the Pharmaceutical Society of Japan, 110(11), 876-884.

54. Byeon, S. W., Pelley, R. P., Ullrich, S. E., Waller, T. A., Bucana, C. D., \& Strickland, F. M. (1988). Aloe barbadensis extracts reduces the production of interleukin-10 after exposure to ultraviolet radiation. J Invest Dermtol, 110, 811-887.

55. Boudreau, M. D., \& Beland, F. A. (2006). An evaluation of the biological and toxicological properties of Aloe barbadensis (miller), Aloe 
Aisha Saleem et al; Sch Int J Anat Physiol, Jan., 2022; 5(1): 1-8

vera. Journal of Environmental Science and Health Part C, 24(1), 103-154.

56. Eshun, K., \& He, Q. (2004). Aloe vera: a valuable ingredient for the food, pharmaceutical and cosmetic industries - a review. Critical reviews in food science and nutrition, 44(2), 91-96.

57. Joseph, B., \& Raj, S. J. (2010). Pharmacognostic and phytochemical properties of Aloe vera linn an overview. Int J Pharm Sci Rev Res, 4(2), 106-110.

58. Kim, K., Kim, H., Kwon, J., Lee, S., Kong, H., Im, S. A., ... \& Kim, K. (2009). Hypoglycemic and hypolipidemic effects of processed Aloe vera gel in a mouse model of non-insulin-dependent diabetes mellitus. Phytomedicine, 16(9), 856-863.

59. He, Q., Changhong, L., Kojo, E., \& Tian, Z. (2005). Quality and safety assurance in the processing of Aloe vera gel juice. Food control, 16(2), 95-104.

60. Shrivastava, N., Mahajan, S., Jain, A., Sharma, P., Kharakwal, A. C., \& Varma, A. (2019). Mutualistic
Interaction of Piriformospora indica (Serendipita indica) with Aloe vera, the wonder plant for modern living. American Journal of Plant Sciences, 10(11), 2002-2011.

61. Gauri, B., Neha, J., \& Farhat, D. (2011). Aloe vera: a valuable multifunctional cosmetic ingredient. International Journal of Medicinal and Aromatic Plants, 1(3), 338-341.

62. Rajeswari, R., Umadevi, M., Rahale, C. S., Pushpa, R., Selvavenkadesh, S., Kumar, K. S., \& Bhowmik, D. (2012). Aloe vera: the miracle plant its medicinal and traditional uses in India. Journal of Pharmacognosy and Phytochemistry, 1(4), 118124.

63. Javed, H., \& Shah, S. N. H. (2021). Mild-Moderate Acne TreatmentMild-Moderate Acne Treatment and Skin Allergic Reaction Treatment Using Aloevera Emulgel-A Case Study. RADS Journal of Pharmacy and Pharmaceutical Sciences, 9(2), 148150. 